\title{
June 1835
}

\section{/69r cont'd/Monday June $1^{\text {st }}$.}

Come to the last month of my stay in Paris. Went to the Hotel Dieu - Roux has a case of pistol wound in a young $\operatorname{man}^{1}$-ball entered anterior to the tendon achille's/69v/\& passed out at the outer ankle, breaking the malleolus ${ }^{2}$ Tapirus[?]-the treatment is the constant application of cold - he has a case of tumor in the internal aspect of thigh three or four inches above knee - he intends operating tomorrow morning. Went on to $\mathrm{H}$. $\mathrm{S}^{\mathrm{t}}$. Louis - was too late for Biett - he has commenced now making his visit at 9 o'clock - went round with Alibert - he had nothing of any importance - he is treating all his cases by local applications - he lectures on Wednesday on the Dermatoses Teignenses $[s i c]^{3}$ - very interesting \& difficult division to treat - At $M^{\mathrm{e}}$. Lachapelle's tonight had very easy manoeuvres - seizing feet of inf ${ }^{t}$, when there is breech presentation - supposing, that any thing should require such an operation.

\section{Tuesday June $2^{\text {nd }}$.}

Went down to Hotel Dieu this morning. Went round with Breschet - nothing very particular - Roux performed extirpation of the tumor this morning - it was osteo sarcoma ${ }^{4}$ $\&$ attached by means of an osseous peduncle ${ }^{5}$ to the femur - this he was forced to cut away with the saw. Mott from New York was at the operation. A very gentlemanly looking man with something of the precise manners of a quaker about him. ${ }^{6}$ Tonight at $\mathbf{M}^{\mathrm{e}}$. Lachapelle's we applied the crochet in presentations of lower extrem ${ }^{\mathrm{s}} . \&$ hips. $^{7}$

\footnotetext{
${ }^{1}$ Dupuytren had held a course at the Hôtel Dieu on gunshot and sabre wounds. (Warner, Against the spirit of system, p. 115.) This would seem to indicate that the presentation of such wounds was not exactly a rare event despite the ban on duelling.

${ }^{2}$ Malleolus: ankle. This is the diminutive of malleus from its supposed resemblance to a mallet.

${ }^{3}$ Dermatoses Teignenses: dermatoses is a general term for skin diseases. Bateman criticises Alibert, to whose lectures the diarist is referring, for confusing Willan's classification of skin diseases by adopting "the ancient confusion of terms". This confusion includes his use of "les teignes" for the Willanist group of porrigos, contagious conditions, marked by the development of pustules and fever. The group includes porrigo scutulata or ringworm. (Bateman, A practical synopsis of cutaneous diseases, pp. xvi, 225-6.)

${ }^{4}$ In the entry for Sunday, November 9,1834 , the diarist writes the term as a single word: osteosarcoma. In this present case the fleshy tumour or excrescence was developing on the femur in the leg.

${ }^{5}$ Osseous peduncle: bony stalk attaching the tumour to the femur.

${ }^{6}$ Valentine Mott M.D, was already medically qualified and became a professor of surgery in New York where he was a medical luminary and President of the Medical Faculty. Already as a young man in 1818-20, he had been co-editor with two other physicians, John Watts, Jun., and Alexander H. Stevens, of the short-lived periodical The Medical and Surgical Register, published in New York. Mott refers to his time in England and in Paris in Travels in Europe and the East, ... during a tour ... in the years 1834, 1835 ... 1841. Mott was particularly impressed with French medicine and counted its leading practitioners among his friends. He believed that the arduous nature of a surgeon's work was responsible for the early demise of many of them including Dupuytren, who died in February 1835. Mott was also fearful of the effect of his work on his own health but perhaps he took comfort from the longevity of Larrey whom he also greatly admired. (Ibid., pp. 33-57.)

${ }^{7}$ Crochet: a curved instrument with a sharp hook for extracting the foetus. The diarist is beginning to gain experience in using some of the obstetric instruments which were at times used for interventions in difficult births. In certain cases the infant did not survive its birth as a result of damage inflicted either deliberately in
} 
Wednesday $3^{\text {rd }}$.

Went this morning to Salpetriére ${ }^{8}$ with Berard - I like him much - he takes great pains with the students. I saw today several cataracts, which had been operated on - a comp ${ }^{d}$. fracture - \& many other cases - At $\mathbf{M}^{\mathrm{e}}$. Lachapelle's commenced the turning in presentation of shoulders - her maxim /70r/ is, whenever left shoulder presents, introduce left hand, when right, pass in right hand. They make everything very complicated in Paris - she has 4 presentations of each shoulder.

Thursday $4^{\text {th }}$.

Went to Hotel Dieu. Nothing particular - bullet wound going on extremely well. A very violent case of burn in a woman. Roux made three incisions to take off the tension I presume - intended to have gone on to Hopital $S^{t}$. Louis, but did not feel well $-\&$ in consequence returned to my room - found a letter from my father dated Boulogne, he was on his way to Paris, \& intended arriving here this Evening - went to the Coach Office, R. des filles $S^{t}$. Thomas at 7 o'clock - \& met them all (my father, the two girls \& John) - quite a load - had horrid plague 9 about lodgings etc, at last obtained some in Hotel Byron, Rue Laffitte took coffee, \& walked about, till I was quite tired. ret ${ }^{d}$. home here completely fagged.

Friday $5^{\text {th }}$.

Slept very little last night - did not get to R. Laffitte [sic] this morning 'till $1 / 2$ past 9 . after $\mathrm{B}^{\mathrm{kft}}$. we sallied forth to the Louvre, Tuilleries \&c. ${ }^{10}$ - did as much as we $\mathrm{c}^{\mathrm{ld}}$. but the weather was too hot to do much - dined in the Palais Royal at at 2 franc place ${ }^{11}$ - miserable stuff.

Saturday $6^{\text {th }}$.

Went with my father to Hotel Dieu ${ }^{12}$ this morning - followed Roux, he slashed away as usual, amongst other things, he introduced a seton into the thick part of the thigh, \& opened

saving the mother, or by accident. According to Hooper, the pincer forceps were "occasionally used by men-midwives to bring the head of the foetus through the pelvis" (Lexicon, p. 593). Mme Lachapelle was of course teaching male medical students, but she also taught female midwives and did herself deliver infants - see June 6 - presumably using the pincer forceps when necessary.

${ }^{8}$ The Salpêtrière was the great Paris hospital renowned for its enlightened treatment of the mentally disturbed under the care of Philippe Pinel (1745-1826) and of J. E. D. Esquirol (1772-1840), who then moved to the asylum at Charenton.

${ }^{9}$ Plague: contemporary colloquial expression for a nuisance.

${ }^{10} \mathrm{He}$ is being very diligent showing his family the sights and the fact that so many of them have managed to come together to Paris indicates that his father's practice must have been fairly successful.

${ }^{11}$ Some of the restaurants in the Palais Royal were among the most famous and frequented in Paris. The best included Véry's, Frères Provençaux, Chartres, and Prévot's. The diarist's family were, however, on this occasion, dining at one of the establishments among "several restaurateurs who give a dinner, including wine, for two francs per head". (Galignani's new Paris guide, p. 184.) As his experience of November 2 showed, these were not always reliable.

${ }_{12}$ As discussed in the Introduction (pp. 1-2), there are in the London and Provincial Medical Directory $(1849$, p. 481) two medical men from the west country with the name of Surrage. The older of the two is Thomas Lyddon Surrage, who gained an MRCS in 1801 and whose address is Clifton, Bristol. The younger Surrage is James, who is listed as gaining an MD from Edinburgh in 1835, the qualification for which the diarist was soon to return to Edinburgh. James Surrage went on to gain an MRCS in 1836 and an LSA. If the diarist's father was a surgeon it is not surprising that he would be interested in seeing the work and techniques of 
one of the large branches /70v/ of the femoral artery - he plugged the wound, after having having [sic] enlarged it considerably, with a branch of a bullet forceps surrounded by linenthe other branch of the forceps was kept pressed on the skin - this stopped the haemorrhage for the time [being], but I dare say, he will be obliged to take up the the femoral hereafter - he removed three cararacts by incision, ${ }^{13} \&$ operated on a recto vaginal fistula, laying both cavities into one - this was extraordinary treatment surely - after this, we went about sightseeing, than which there is nothing more tiresome - had capital dinner today with Champagne. $\mathbf{M}^{\mathrm{e}}$. Lachapelle $\mathrm{c}^{\text {ld }}$. not lecture tonight, as she was with a woman in labor.

\section{Sunday $7^{\text {th }}$.}

Went to Hop'. La Charite with my father this morning to show him Velpeau. His are certainly good wards - he had a case of Varicocele, which he had treated by an apparatus, different from, but on the same principle as that of Breschet[']s - Velpeau introduces a pin through the scrotum, posterior to the varicose veins $\&$ winds round the two extremities a piece of cotton or silk in the same manner as in harelip /71r/ operation - the cord string thus pressing on the veins gradually cut them through $\&$ they are thus obliterated. ${ }^{14}$ probably this is more simple, \& consequently superior to the plan of Breschet's - breakfasted at the Café Anglais, afterwards went to the Eglise de $S^{t}$. Eustache ${ }^{15}$ to see High Mass - this is a fine old church - for the first time I saw the Sacrament administered according to the rights of the Church of Rome. Such a mockery of religion I think, I never before beheld. We went to the Chapel Marboeuf [sic] - this I was not before aware was a Church, in which the English Episcopalian service was performed ${ }^{16}$ - it is exceedingly neat $\&$ does great credit to the taste of the reverend clergyman, who superintended its erection ${ }^{17}$ - we dined in the Palais Royal at the Café Perigord ${ }^{18}$ - had a good dinner with Champagne - walked in the Tuilleries

eminent French surgeons. It is possible that the diarist took his father initially to the Hôtel Dieu because, being a little further out, it did not attract the crowds of the more central hospitals and so there was a greater chance of seeing something.

${ }^{13}$ Incision: this was extraction of the cataract.

${ }^{14}$ As the diarist observes, the principle behind the treatment for varicocele of the two surgeons is the same. His prediction of the superiority of Velpeau's method is more debatable.

${ }^{15} \mathrm{St}$. Eustache, in the 3rd arrondissement, was the largest church in Paris after Notre Dame. It was begun in 1532 and contained beautiful and ancient stained glass windows and a pulpit which originally belonged to Notre Dame but which had fallen into the possession of the church at the Revolution. The church also contained a magnificent organ and was the burial place for a number of distinguished individuals including the painter Charles de Lafosse (1636-1716), the statesman Jean Baptiste Colbert (1619-83) and the admiral, Anne Hilarion de Cotentin, Comte de Tourville (1642-1701). (Galignani's new Paris guide, pp. 86-9.)

${ }^{16}$ Chapel Marboeuf: presumably the "Chapel" was the Hôtel Marboeuf in the avenue de Neuilly just beyond the Champs Élysées which Galignani lists as one of the three English Protestant churches and the one with "Evangelical preachers". Since the church was in a former café and the parsonage in a former hotel building it is little wonder that the diarist was unaware of the church. The other two Protestant churches were the Ambassador's Chapel, the well-attended Anglican Church in Paris and the Oratoire in rue St. Honoré where the services were described as "American worship" resembling that of the Dissenters in England denominated "Independents". (Galignani's new Paris guide, facing p. i, and pp. 141-2.) Both Galignani and Hillairet (vol. 2, pp. 96-7) give the name of the nearby avenue and the road to the diarist's Chapel as "Marboeuf".

${ }^{17}$ A few years earlier, the Reverend Lewis Way had purchased a former café and the Hôtel Marboeuf along with the associated public garden for the establishment of the church and parsonage. Galignani describes the church as remarkably neat and comfortable and notes its organ. (New Paris guide, p. 141.)

${ }^{18}$ The Café Périgord was another of the best restaurants in Paris. 
gardens, ret ${ }^{\mathrm{d}}$. to Palais Royal - took lemonade, $\& \mathrm{I} \mathrm{ret}^{\mathrm{d}}$. home in the midst of tremendous lightning - I however escaped the rain.

Monday $8^{\text {th }}$.

Went to Rue Lafitte this morning, found Mr. Cassidi ${ }^{19}$ there, who was about to accompany us to Versailles today. We all went with J. Bird to breakfast in the Café Anglais \& afterwards started for Versailles in the Diligence ${ }^{20}$ - we walked $/ 71 \mathrm{v} /$ round the grounds - saw the waterworks, le grand et le petit Trianon ${ }^{21} \&$ the gardens - ret ${ }^{d}$. to the Restaurants to dinner after some little trouble, succeeded in getting a Cuckoo $[\text { sic }]^{22}$ to take us all home. Diligences all full - had glorious fun returning.

Tuesday $9^{\text {th }}$.

Went down to Hotel Dieu this morning, Roux endeavoured to reduce a dislocation of two months' standing - failed - did not employ pullies - the man, whose artery he opened, is looking miserably blanched - he will die of haemorrhage in all probability - went into the grand gallery of the Louvre today-I \& my father went to the waxworks ${ }^{23}$ Rue Montesquieuafterwards all went off to the Pere la Chaise - dined at the Café de Paris on the Boulevards \& visited the gardens [ sic] of the Tivoli ${ }^{24}$ - illuminations, bands, fireworks etc constituted the amusements.

Wednesday $10^{\text {th }}$.

My father came to call on me this morning, \& we went together to La Pitié. Lisfranc did not come to the Hospital - we saw Blandin ${ }^{25}$ remove the thigh in a case of white swelling of $/ 72 \mathrm{r} /$ the knee - I do not think he performed it very well - he seemed to hack it not a little - breakfasted, met the girls in the garden of plants - unfortunately no museums open - I \& my father went off to British Embassador's ${ }^{26}-\mathrm{c}^{\text {Id }} \cdot$ take $^{27}$ no places to

\footnotetext{
${ }^{19}$ It has not been possible to identify Cassidi.

${ }^{20}$ Diligence: a public stage coach which carried passengers - and parcels - “ $a$ des jours et $a$ des heures fixes". In other words the diligences ran according to a timetable.

${ }^{21}$ Le Grand-Trianon mansion was built by Louis XIV for whom it was a favourite retreat. It was also a favourite residence of Louis XV and Louis XVI. The smaller mansion of Le Petit-Trianon and its gardens were constructed under Louis $\mathrm{XV}$, who was there when he was attacked by a contagious disease from which he died. His wife had the gardens laid out in the English style. (Galignani's new Paris guide, pp. 730-7.)

${ }^{22}$ Cuckoo: a "coucou" was a small coach running from Paris to the suburbs.

${ }^{23}$ The waxworks were in the Salon de Figures. Clearly Galignani was not enamoured of this place because his entry is the shortest in what is generally a detailed guide. It reads: "Those who admire such exhibitions may be amply gratified here". (New Paris guide, p. 564.)

${ }^{24}$ Le Jardin de Tivoli, situated on rising ground, was the most celebrated of the public gardens in Paris. It had only fairly recently introduced public amusements such as, in the summer months, open-air fêtes with balls, concerts, conjuring acts, acrobatics, fireworks and illuminations. According to Galignani, the Tivoli Garden was "much more lively than Vauxhall", which could be considered its counterpart in London. The cost of entry was 3 to 6 francs, depending on the entertainment, but "strangers" such as the diarist and his family and fellow students would be admitted for only 1 franc each. (New Paris guide, pp. 566-7. )

${ }^{25}$ The surgeon Philippe Frédéric Blandin (1798-1849) was, early in his career, interested in dentistry, on which he wrote Anatomie du système dentaire (1836). He also wrote on transplantation, Autoplastie, ou restauration des parties du corps (1836).

${ }^{26} \mathrm{He}$ seems to have elided Embassy and Ambassador, unless he simply meant "the Ambassador's place".

${ }^{27} \mathrm{He}$ meant that he was unable to book a ticket.
} 
Havre, ${ }^{28}$ obliged to go by way of Boulogne - ret $^{d}$. to Garden of plants at 4 instead of $2-c^{\text {ld }}$. not consequently go to Gobelins, as we had intended - saw the Pantheon, Eglise de $S^{t}$. Geneviéve $^{29}$ \& walked after dinner in Garden of Luxembourgh-I went to Mad ${ }^{\text {e. Lachapelle's }}$ in the Evening - applied forceps in case of head presentation, when it has descended low.

Thursday $11^{\text {th }}$.

Went this morning to Rue Lafitte - breakfasted, went shopping, afterwards to Hotel des Invalides $\&$ ret $^{\mathrm{d}}$. to the exhibition of Sevres Porcelain Rue Rivoli - nothing more than a miserable shop here, instead of a magnificent exhibition - dined \& my father \& sisters left at 6 in the Evening - heartily tired of France, Paris, everything \& everybody French - I walked about the Garden of Tuilleries for some time, \& afterwards took cup of tea with Bird.

Friday $12^{\text {th }}$.

Went this morning to Hotel Dieu - the man whose artery Roux opened, died of haemorrhage - pure murder ${ }^{30}-$ ret $^{\mathrm{d}}$. \& went over some of the bones of trunk - at $\mathbf{M}^{\mathrm{e}}$. Lachapelle's this Evening, had application of forceps in case of head presentation, before passing the brim of pelvis.

Saturday $13^{[\text {th }]}$.

Was at Roux's this morning - operation for fistula in ano \& for popliteal aneurism $-c^{\text {ld }}$. not see either, on account of crowding in of students $-\mathbf{M}^{\mathbf{e}}$. Lachapelle still application of forceps.

172v/ Sunday $14^{\text {th }}$.

Engaged to breakfast with J. Bird this morning - went down at 9 - afterwards called on Mr. Cassidi went to the temple ${ }^{31}$ - unfortunately too late - went on to

\footnotetext{
${ }^{28}$ The route between England and Paris via Le Havre provided the most comfortable travelling experience. Lafitte and Company ran diligences from the Hôtel de Bienvenu, or it was possible to take one of the messageries royals (rapid coaches, which, though primarily for the mail, carried passengers also) from the Hôtel de l'Europe to Le Havre. Forty pounds of luggage per person were allowed. No doubt the diarist's family shared his load. From Le Havre it was possible to take one of the two large powerful and handsome steamboats which travelled twice a week during the summer to Southampton, making the journey in eleven or twelve hours. Southampton on the south coast would have been a convenient landing place for his family's onward journey to Clifton. (Galignani's new Paris guide, pp. $\mathrm{x}$-xi.)

${ }^{29}$ The Église de Ste. Geneviève, or Panthéon, was initially dedicated to the apostles Peter and Paul, it became a celebrated abbey. Ste. Geneviève, who became the patron saint of Paris, was buried there in 512 , and the church was rededicated to her. It was rebuilt in the eighteenth century and almost suffered the destruction of its costly dome which involved installing more robust and less elegant columns of support. In 1791, the National Assembly decreed that it should be consecrated as the burial place for the French who had shed lustre on their country; it was changed into a pantheon. The remains of Voltaire and Jean-Jacques Rousseau were transported there. In 1806 Napoleon decreed that while remaining a pantheon it should become again a place of divine worship. This took place in 1822 . Visitors were able to view the dome and the vaults daily from 10 a.m. to 6 p.m. (Galignani's new Paris guide, pp. 135-9.)

${ }^{30}$ It seems that one of the diarist's abiding memories will be of the brutality, as he sees it, of some of the surgeons - including Roux - whose work he has witnessed during his months in France.

${ }^{31}$ The Temple was a new chapel built in 1832 and the land on which it stood was associated with the Knights Templars, founded in Jerusalem in about 1118 , whose principal French establishment was situated in what came to be named rue du Temple. Before the Revolution it consisted of two distinct parts, the Temple
} 
$S^{t}$. Denis ${ }^{32}$ - arrived at the Church at 1 o'clock - obliged to wait 'till 3 before the old Verger $\mathrm{c}^{\text {ld }}$. show us round \& take us to the tombs - they were not very well worth seeing - but I did not wish to leave Paris without visiting them - walked across the country from $S^{t}$. Denis to the Bois de Boulogne - behind Montmartre ${ }^{33}-$ ret $^{d}$. home late in the Evening somewhat fatigued.

Monday $15^{\text {th }}$.

Went down to the Hotel Dieu this morning, followed Breschet, no case of much importance, he intends now to give lectures on the cases in the wards four times a week. I wish, he had commenced this plan earlier in the season, I might then have been more favourably situated for learning Surgery - studied some of the bones. $-\mathbf{M}^{\mathrm{e}}$. Lachapelle on the application of the forceps.

Tuesday $16^{\text {th }}$.

Went to the Hôpital du Midi - Mr Mott of New York was there. M. Ricord explained to him all the plans \& experiments he had made in reference to the Venereal disease, proving, that the matter of chancres \& Gonorrhoea was altogether different in nature - his treatment, the effects of inoculation - etc M. Mott was very much pleased \& said he $w^{\text {ld }}$. visit him again. Went to the Louvre to meet Mess ${ }^{\text {rs }}$. Cassidi \& Bird. Afterwards took my place to Boulogne from Rue [des] Messageries /73r/ Royales - ret ${ }^{d}$. to dinner $-\mathbf{M}^{\mathrm{e}}$. Lachapelle's in the Evening.

Wednesday $17^{\text {th }}$.

Went down to the Hotel Dieu - M. Breschet had some very good cases - one particularly of fracture of one leg \& considerable bruize [sic] of the other - he was treating the case by the constant application of a stream of cold water - he gave me a certificate of attendance on his teet visits \& Clinique, since November last - breakfasted with Bird, went to the Conservatoire des Arts et Metiers ${ }^{34}-$ this we $c^{\text {ld }}$. not see, being

proper and the palace of the grand prior. The earlier Temple had passed into the hands of the Order of Malta. Over the years it had served successively as a deposit for the kings of France, a repository for the archives of the grand prior of Malta, a prison and more recently as a convent. Prior to the Revolution, the Temple proper had associated with it hotels and gardens, modest dwellings for tradesmen, artists and insolvent debtors who took refuge in the place. A bazaar had been allowed to trade to increase the revenues of the grand prior. (Galignani's new Paris guide, pp. 144-6.)

${ }^{32} \mathrm{~S}^{t}$ Denis: the original church, built in 1684 for a community of nuns of the Adoration perpétuelle du St. Sacrement, had been demolished in 1828 and the rebuilding seems to have been completed by the time of the diarist's visit. (Galignani's new Paris guide, p. 105.)

${ }^{33}$ Montmartre: this hill lay at the time just outside the walls of Paris and had an ancient village with fine views of the city and important telegraphs communicating with Bordeaux, Brest and Spain situated on it. The name was thought to be derived either from Mon Martis since, it was claimed, a temple to Mars had once existed there or from Mons Martyrum since it was supposedly where St. Denis and his companions had suffered martyrdom. The village was famous for its windmills and guingettes - popular cafés. The hill, which has an interesting geological structure and is celebrated for its fossil remains, also had quarries which supplied Paris with gypsum for medical use in plaster of Paris. See January 20, note 141. (Galignani's new Paris guide, pp. 655-6.)

${ }^{34}$ The Conservatoire Royal des Arts et Métiers was a national repository of machines, models, drawings, etc., for the improvement of machinery and implements connected with factories, agriculture and other branches of industry. Established in 1794 at the suggestion of Bishop Grégoire, a member of the National Convention, it was formed from three original repositories. In 1811 the Conservatoire acquired a school to provide instruction in 


\section{7-18 June 1835}

closed $^{35}$ - walked around the Boulevards, took a Cuckoo for Vincennes, $c^{\text {ld }}$. not see the castle $^{36}$ without permission of Governor, walked across the "Parc" to Alfort ${ }^{37}$ \& Charenton ${ }^{38}$ - saw the Veterinary School \& the bridge so hotly contested by the students in 1815 against the Allies ${ }^{39}$ - dined \& ret ${ }^{d .}$ to Paris. $\mathbf{M}^{\mathrm{e}}$. Lachapelle did not lecture this Evening, I therefore accepted Bird's invitation to take a cup of tea with him.

Thursday $18^{\text {th }}$.

The anniversary of Waterloo, ${ }^{40}$ went down to Hotel Dieu - met M. Cassidi at a café to breakfast [sic] - saw the paintings in the Luxembourgh, ${ }^{41}$ went to the Hospice des Enfans Trouvés $^{42}$ - this is an exceedingly curious institution - it seems so strange to see

drawing, descriptive geography, and mathematics, and in the application of mathematics to timber and stone cutting and the calculations associated with the machines. Patents together with the descriptions, plans, design and models had to be deposited at the Conservatory, which printed, engraved and published them.

${ }^{35}$ The establishment was open only on Thursdays and Sundays.

${ }^{36}$ The château at Vincennes dated from the thirteenth century and had been a royal palace. It was now a state prison.

37 "Parc": this was probably the successor to the original forest area, which still abounded with game and was a favourite weekend spot for Parisians. Alfort was a village about two miles beyond Vincennes to the south-east of Paris. The diarist's interest was the veterinary school established in the buildings of another ancient castle of the region. Founded in 1766, several illustrious professors taught there, including Félix Vicq d'Azyr (1748-94), L.J.M. Daubenton (1716-99) and A.F. Fourcroy (1755-1809). A library of domestic zoology and a cabinet of comparative anatomy and another of pathology were open to the public. The college also had a botanical garden, hospitals for sick animals, an experimental science laboratory, a pharmacy, a school of practical agriculture, ground for cultivating forage, a flock of sheep for experiments on crossing breeds and the improvement of wool, an amphitheatre for lectures on veterinary medicine and rural economy, as well as farriers and a bee house. (Galignani's new Paris guide, pp. 618-19.)

${ }^{38}$ The village of Charenton's ancient bridge was the key to taking Paris and was therefore often under attack. The Maison Royale de Charenton, founded in 1644, treated the insane of both sexes. In 1797 it had been taken over by the government from the religious order running it. Although originally intended for those whose condition suggested hope of cure, the intake was widened to receive less hopeful cases. The mode of treatment would in England have been described as moral management and was based on the enlightened views of Philippe Pinel and J. E. D. Esquirol, who went to Charenton from the Salpêtrière.

${ }^{39}$ The bridge consisted of ten arches, six of stone and four of wood. The latter were cut in the incident of 1814 when the invading armies advanced but the students of the Veterinary School at Alfort who were trying to defend the bridge had to withdraw. (Galignani's new Paris guide, p. 634.)

${ }^{40}$ It was twenty years since the June 1815 battle, which, as the diarist has already noted, Napoleon also claimed as a victory. See entry for November 7,1834 .

${ }^{41}$ The original paintings in the gallery of the Luxembourg Palace, including twenty-four large works by Rubens, were removed in about 1780, replaced after the Revolution, and moved again in 1815 to be hung in the Louvre. Their place was later filled by a splendid collection of what were then modern French paintings. Foreigners were admitted daily except Mondays, between 10 a.m. and 4 p.m. on production of their passports. (Galignani's new Paris guide, pp. 192-3.)

${ }^{42}$ Hospice des Enfans Trouvés: the foundling hospital in rue d'Enfer for the receipt of abandoned children who could be left there at any time on any day, as the diarist describes. The history of the practice in France, as elsewhere, of dealing with foundlings has been a chequered one, including their sale by unscrupulous individuals charged with their care. In the early seventeenth century, a priest, St. Vincent de Paul (1580-1660) acquired an asylum for them near Porte St. Victor where they were cared for by the Sisters of Charity, also established by St. Vincent de Paul. It was said that the nuns initially cared for the healthy ones and abandoned the rest. Further financial support was obtained to stop this practice and after the Revolution the foundling hospital was established. At the time 5,000 to 6,000 children were received annually and maintained until they were twelve years of age, after which they were found some occupation or trade, or if unable to take up a job were transferred to the Orphan Asylum. On arrival in the hospice, the infants, if healthy, could be put into the care of peasant women, who came to the hospital and stayed there for a few days before leaving with the children. The women were periodically 
cradles arranged $/ 73 \mathrm{v} /$ around long wards in double rows - any ehild person can gain admittance for a child by merely ringing a bell \& placing the little one in a basket place, which is turned around on its axis - the person placing the child there, is not seen, nor is it known whose the child is - we saw afterwards the Eglise de Val de Grâce $^{43}$ - this is one of the most splendid churches I have seen - the ceiling is particularly magnificent ${ }^{44}$ - went to the Museum d'Histoire Naturelle ${ }^{45}$ - this is exceedingly extensive - obliged to hurry over it very much - Saw also the Gallerie and the Ecole de Botanique.

\section{Friday $19^{\text {th }}$.}

Went to Hotel Dieu - the poor man, from whose thigh the osteosarcoma was removed is a little better but tremendous suppuration - the aneurism case going on very badly, something like gangrene of toe - after breakfast went across [to] $\mathbf{M}^{\mathrm{r}}$. Cassidi - called at Ambassador's with passport - took leave of $\mathbf{M}^{\mathrm{r}}$. Newstead's family. Went to prefecture of police - had everything properly arranged - finished the forceps with $\mathbf{M}^{\mathrm{e}}$. Lachapelle this Evening.

Saturday $20^{\text {th }}$.

My time is now becoming very short, went out before breakfast to buy some portraits, \& views of Paris - afterwards called on Prudie[?]. ${ }^{46}$ Bought a watch for $220 \mathrm{f}^{\mathrm{r}}$. - cheap if

inspected and received an allowance for looking after and ensuring the education of the children until they were twelve years old. (Galignani's new Paris guide, pp. 383-6.)

${ }^{43}$ The Église Val de Grâce, a magnificent church whose grandeur the diarist acknowledges, was begun in 1645 by Anne of Austria, consort of Louis XIII, in fulfilment of a vow that she would found a church and convent if her desire for an heir to the throne were fulfilled. She gave birth to Louis XIV. The church was completed and dedicated in 1665 and destined to receive the hearts of the princes and princesses of the royal family. Under Napoleon the convent was converted into a military hospital and in 1826 the church, which had served as a store house for the military hospitals, was repaired and restored for worship. (Galignani's new Paris guide, pp. 375-7.)

${ }^{44}$ The painting of the dome, in fresco on stone, contains more than 200 figures of huge proportions representing the glory of heaven. It was the largest work of its kind in Europe.

${ }^{45}$ Museum d'Histoire Naturelle: properly the Musée d'Histoire Naturelle. Founded in 1635 by Louis XIII and, surprisingly, not closed during the Revolution, this museum in the Jardin des Plantes contained a truly large collection. The galleries were devoted to specimens from the animal and plant kingdoms, a menagerie of living animals, a library of natural history books, an amphitheatre with laboratories, etc. for public lectures on every branch of science related to natural history. Several eminent individuals have been associated with the Museum including the celebrated naturalist Georges Buffon, appointed superintendent in 1739. (Galignani's new Paris guide, pp. 502-29.) The diarist was in such a hurry that, in the exhibits devoted to Comparative Anatomy, he missed the skeleton of Sarah Baartman, a Khoisan woman, known as the Hottentot Venus - to whom he had made reference soon after arriving in France (November 3, note 47) - and whose skull had been stolen from the museum almost seven years earlier in December 1827. (Ibid., p. 525.)

${ }^{46}$ The diarist could be referring to Alfred Prideaux from Cornwall, who had gained an MRCS in 1834 and an LSA in 1836. (London and Provincial Medical Directory, 1849, p. 395.) He is less likely to have been referring to Jas. Denholm Pridie of Stockton in County Durham who qualified with an MRCS from Edinburgh six years later in 1841 and worked as a Resident Medical Officer in the Royal Edinburgh Lunatic Asylum, before taking up a post as surgeon to the Stockton Dispensary. If this later Pridie is the subject of the diarist's comment then he would have been visiting Paris before embarking on his medical course. 
good - went to the Gobelins, $/ 74 r /$ called at $D^{r}$. Woodhouse's ${ }^{47}$ - has changed his lodgings - went to $\mathbf{M}^{\mathrm{e}}$. Lachapelle's - finished with her this Evening - received all my books from the binder - paid very little, only $28 \mathrm{f}^{\mathrm{4}}{ }^{48}$ wish I had had all done in same manner - packed up a few things - my skeleton box with case holds all my books - very convenient. $^{49}$

\footnotetext{
${ }^{47}$ Dr Woodhouse: this could have been Richard Thomas Woodhouse from Reading in Berkshire who had gained an MD in Edinburgh three years earlier in 1832, so he and the diarist would have overlapped as students at that university. He had already gained a post as Senior Physician to the Reading Dispensary and may have come to Paris to gain some special experience. (London and Provincial Medical Directory, 1849, p. 449.)

${ }_{48}$ Thus not only was the price of books in Paris much cheaper than in England, but also the hard binding of the usual paper-backed books still typical in continental bookshops.

${ }^{49}$ Charming image of a skeleton travelling to England surrounded by books.
} 